\title{
Subclinical oral involvement in patients with endemic pemphigus foliaceus
}

\author{
Ana Maria Abreu-Velez ${ }^{1}$, Michael S. Howard ${ }^{1}$, Héctor Jose Lambraño Padilla ${ }^{2}$, Sergio Tobon-Arroyave ${ }^{3}$
}

1 Georgia Dermatopathology Associates, Atlanta, GA, USA

2 Dentist, El Bagre, Antioquia, Colombia

3 School of Dentistry, University of Antioquia, Medellin, Colombia

Key words: endemic pemphigus foliaceus, oral mucosa, IgA, cell junctions, salivary glands, secretory immunoglobulin A

Citation: Abreu-Velez AM, Howard MS, Lambraño Padilla HJ, Tobon-Arroyave S. Subclinical oral involvement in patients with endemic pemphigus foliaceus. Dermatol Pract Concept. 2018;8(4):252-261. DOI: https://doi.org/10.5826/dpc.0804a02

Received: January 30, 2018; Accepted: July 12, 2018; Published: October 31, 2018

Copyright: (C2018 Abreu-Velez et al. This is an open-access article distributed under the terms of the Creative Commons Attribution License, which permits unrestricted use, distribution, and reproduction in any medium, provided the original author and source are credited.

Funding: This work was funded by Georgia Dermatopathology Associates; Mineros SA, Medellin, Colombia; Hospital Nuestra Señora del Carmen, El Bagre, Colombia; The Embassy of Japan in Colombia; The School of Dentistry, University of Antioquia; and El Bagre Mayoral Office.

Competing interests: The authors have no conflicts of interest to disclose.

All authors have contributed significantly to this publication.

Corresponding author: Ana Maria Abreu-Velez, MD, PhD, Georgia Dermatopathology Associates, 1534 North Decatur Road, NE, Suite 206; Atlanta, GA 30307-1000 USA. Email: abreuvelez@yahoo.com

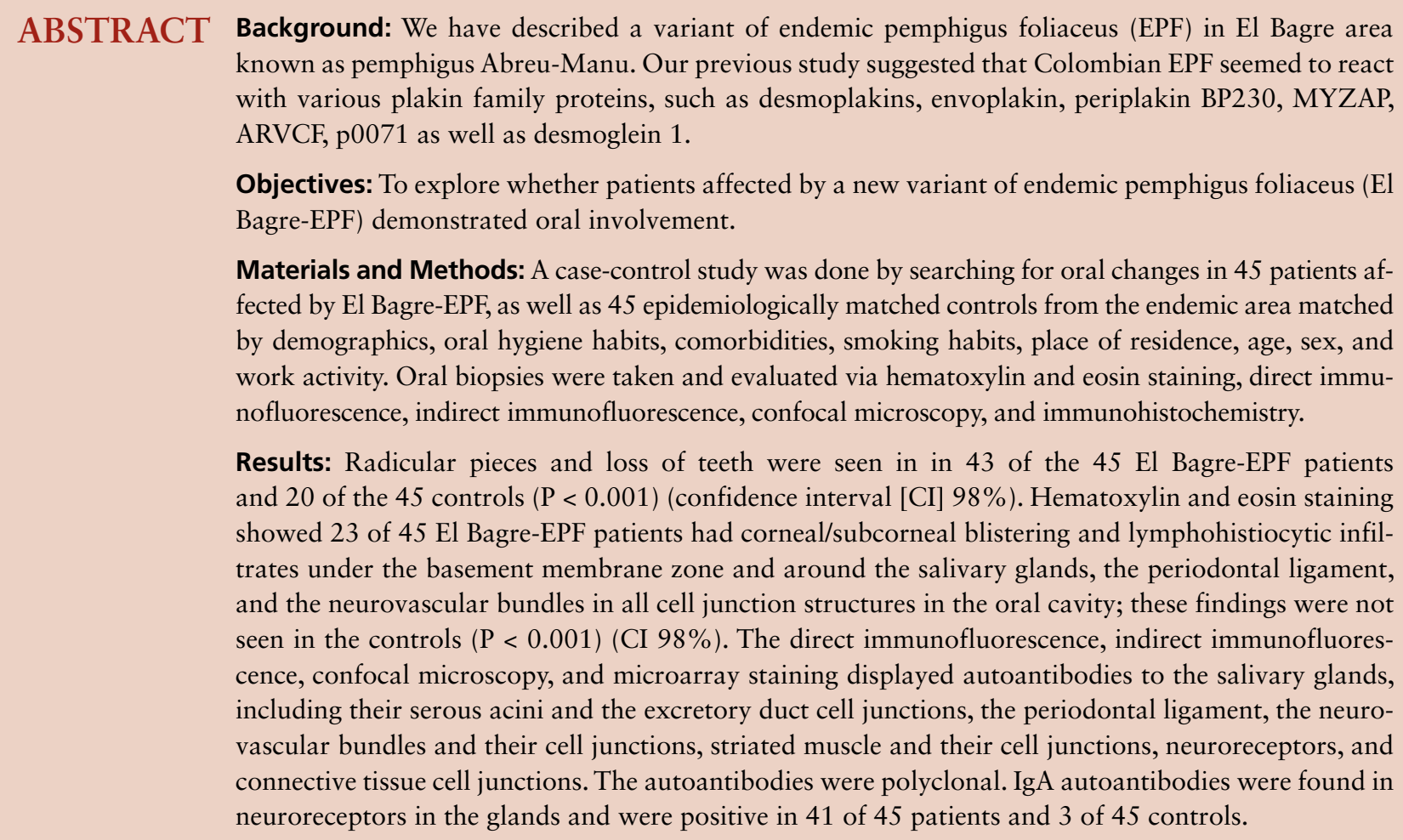


ABSTRACT Conclusions: Patients affected by El Bagre-EPF have some oral anomalies and an immune response, primarily to cell junctions. The intrinsic oral mucosal immune system, including IgA and secretory IgA, play an important role in this autoimmunity. Our data contradict the hypothesis that pemphigus foliaceus does not affect the oral mucosa due to the desmoglein 1-desmoglein 3 compensation.

\section{Introduction}

We have described a new variant of endemic pemphigus foliaceus in El Bagre, Colombia, South America (El Bagre-EPF, or pemphigus Abreu-Manu) [1-5]. El Bagre-EPF differs from other types of EPF clinically, epidemiologically, and immunologically. Previous studies have shown that patients affected by EPF in Brazil have some oral findings [7, 8]. Selected authors have described the presence of autoantibodies using hematoxylin and eosin (H\&E) staining, direct and indirect immunofluorescence (DIF, IIF), and electron microscopy studies [9-11]. In the current study, our aim was to search for oral clinical lesions and an oral autoimmune response in patients affected by EPF in El Bagre, Colombia (El Bagre-EPF) [1-5] and to compare our findings with those described in the medical literature for Brazilian EPF patients.

\section{Materials and Methods}

\section{Statement on Ethics}

A human quality assurance review board approved the studies at the Hospital Nuestra Señora del Carmen in El Bagre, and all participants provided signed consent. The studies have been approved by the appropriate institutional and/or national research ethics committee and have been performed in accordance with the ethical standards as established in the 1964 Declaration of Helsinki and its later amendments or comparable ethical standards. We tested 45 patients affected by El Bagre-EPF and 45 controls from the endemic area matched by age, sex, demographics, comorbidities, work activities, weight, exposure to chemicals, socioeconomic status and income, and food intake. Thirty controls from the endemic area were healthy individuals. The other controls included patients with psoriasis, scleroderma, and chronic drug eruptions. All of the tests were performed in both cases and controls. The patients and controls were evaluated by H\&E histology, DIF, IIF, confocal microscopy, immunoblotting, immunoprecipitation, and enzyme-linked immunosorbent assay. Only patients meeting diagnostic criteria for El Bagre-EPF were included; specifically, they had to display clinical and epidemiological features described for this disease, live in the endemic area [1,2], and have serum displaying intercellular staining (ICS) between epidermal keratinocytes and the basement membrane zone (BMZ) of the skin via either DIF or IIF using fluorescein isothiocyanate (FITC) conjugated monoclonal antibodies to human total $\operatorname{IgG}$ or IgG4, as described elsewhere [1-5]. Furthermore, each patient had to be positive by immunoblotting for reactivity against Dsg1 [2, 3], as well as for plakin molecules; each patient's serum immunoprecipitated a concanavalin A affinity-purified bovine tryptic $45 \mathrm{kDa}$ fragment of Dsg1 [4]; and each patient's serum had to yield a positive result using an enzyme-linked immunosorbent assay test when screening for autoantibodies to pemphigus foliaceus antigens [5].

Oral mucosa from the buccal mucosa was biopsied; 2 biopsies were taken, 1 for H\&E staining and immunohistochemistry (IHC) and 1 for DIF. The skin was tested as previously described [1-5].

\section{DIF, IIF, and IHC}

We performed DIF and IIF as previously described [2, 3]. All samples were run with positive and negative controls. Several years ago, the first [12] discovered new autoantigens to several organs other than the skin. Because of the complexity of the immune response in these patients, we contacted other experts, including Dr. E. H. Beutner in the USA, Dr. Takashi Hashimoto in Japan, and Dr. W. W. Franke (formerly a professor at the University of Heidelberg in Germany). All agreed that our data indicated new autoantigens. We sent identical serum for study to these scientists, and all agreed this disorder was unique. A few months later, the primary owner of Progen Biotechnik (Heidelberg, Germany), Dr. W. W. Franke, commercialized these antibodies. Thus, we used the following antibodies from Progen: antiARCVF (Armadillo repeat gene deleted in velocardiofacial syndrome; cat. no. GP155), anti-desmoplakin (DP) 1 and DP2 (cat. no. 65146), anti-p0071 (cat. no. 651166), and anti-MYZAP (myocardium-enriched zonula occludens1-associated protein; cat. no. 651169). Secondary antibodies were obtained from Thermo Fisher Scientific (Waltham, MA, USA), for ARCVF we used Alexa Fluor 555 goat anti-guinea pig, while for DP1, DP2, p0071, and MYZAP we used goat anti-mouse Texas red-conjugated IgG. We also used rabbit anti-junctional adhesion molecule 1 (JAM-A) (Thermo Fisher Scientific), as this antibody is positive against gap junction. We classified our findings as negative (-), weakly positive $(+)$, moderately positive $(++)$, and strongly positive $(+++)$. For IHC, we utilized antibodies for $\alpha$-1-antitrypsin, human matrix metalloproteinase 9 (MMP9), human tissue inhibitor of metalloproteinases 1 (TIMP-1), metallothionein, 
and urokinase type plasminogen activator (all from Dako; Agilent Technologies, Santa Clara, CA).

\section{Questionnaires on Oral Habits}

Deleterious oral habits include bruxism parasomnias, traumatic brain injury, neurological disabilities, nail biting, morphological factors, temporomandibular joint dysfunction, tongue thrusting, mouth breathing, smoking habits, and chewing on plants and/or gum. Other questions included how often toothbrushes were changed, use of dental floss, dental visits, and frequency of brushing teeth.

\section{Imgenex Microarray IIF Using Frozen Normal Oral Organs}

Our microarray work was performed as described for our IIF; as our antigen source, we used a commercial human tissue microarray in duplicate from Imgenex Corporation (San Diego, CA, USA).

\section{Confocal Microscopy}

Confocal microscopy was performed as previously described $[5,6]$.

\section{Statistical Analysis}

We used the Fisher exact test to compare 2 nominal variables (eg, positive and negative) of the antibody response. $\mathrm{P}<0.01$ with a $98 \%$ degree of confidence or more was considered statistically significant. We used the software GraphPad QuickCalcs (GraphPad Software Inc., La Jolla, CA, USA).

\section{Results}

\section{Questionnaires on Oral Habits}

Deleterious oral habits did not show any statistical significance between the cases and controls. The oral health habits were poor in all study participants (37/45 patients and 38/45 controls). Most never visited the dentist for economic reasons (43/45 patients and 42/45 controls), brushed their teeth at most once or twice a week (32/45 patients and 33/45 controls), and rarely used dental floss (40/45 patients and 41/45 controls). Overall, 42 of 45 El Bagre-EPF patients were taking oral prednisone in doses ranging from 5 to $40 \mathrm{mg} /$ day. In addition, 3 of 45 controls were taking prednisone for systemic sclerosis or for psoriasis $(\mathrm{P}<0.001)$ (confidence interval $[\mathrm{CI}] 98 \%$ ).

\section{Oral Evaluation}

The most significant alteration in the El Bagre-EPF patients was the finding of multiple radicular pieces and loss of teeth in 43 of $45 \mathrm{El}$ Bagre-EPF patients and in 17 of 45 controls ( $\mathrm{P}<0.001$ ) (CI 98\%) (Figure 1a). Furthermore, 14 of $47 \mathrm{El}$ Bagre-EPF patients had no teeth (Figure 1). Leukoedema was found in 6 of $45 \mathrm{El}$ Bagre-EPF patients and in no controls.
Large varicosities were found in 10 of 45 patients at the base of the involved lingual renine veins or in vessels of the ventral surface of the tongue or the floor of the mouth, with no control varicosities recorded. Small ulcers were seen in the palatal mucosa in 5 of 45 El Bagre-EPF patients. Dental caries were also found in most participants.

\section{H\&E Staining}

The H\&E staining showed that 23 of 45 El Bagre-EPF patients had corneal and/or subcorneal epidermal blisters and dermal edema and lymphohistiocytic infiltrates under the BMZ and around the salivary glands (including their serous acini and the excretory duct cell junctions and the neurovascular bundles). These findings were not observed in the controls $(\mathrm{P}<0.001)$ (CI 98\%) (Figure 1b).

\section{DIF, Confocal Microscopy, and Imgenex Microarray Studies}

In Table 1, we present the results of our autoantibody findings in the skin and the oral mucosa, including their strength and colocalization with commercial antibodies to ARVCF, MYZAP, DP I-II, p0071, and JAM-A. In both anatomic areas, autoantibodies were polyclonal in nature with a prevalence of IgG and fibrinogen in the acute cases; in chronic cases ( $>2$ years of disease), IgM was most commonly seen $(\mathrm{P}<0.001)$ (CI 98\%) (Figure 1). The controls were uniformly negative. The El Bagre-EPF patients' periodontal ligaments have polyclonal autoantibodies on 43 of 45 compared to 0 of 45 controls. Multiple structures in the oral mucosa displayed their strongest autoreactivity with $\operatorname{IgA}$ compared with their anatomic correlates in the skin $(\mathrm{P}<$ 0.001) (CI 98\%) (see Table 1). The neuroreceptors in the salivary glands were very positive $(+++)$ in most El Bagre-EPF patients compared with the controls $(\mathrm{P}<0.001)$ (CI 98\%). The controls demonstrated secretory $\operatorname{IgA}$ in the salivary glands, including serous acini and the excretory duct cell junctions; these findings were also noted in the El BagreEPF patients $(\mathrm{P}<0.001)(\mathrm{CI} 98 \%)$ (Figures 1 and 2$)$. The El Bagre-EPF autoantibodies colocalized $100 \%$ with the commercial antibodies to ARVCF, p0071, DP I-II, MYZAP, and ARVCF ( $\mathrm{P}<0.001)$ (CI 98\%). Albumin autoantibodies also colocalized with JAM-A used as control. When using antibodies to IgG we observed neutrophil extracellular traps coming from the dermal vessels. In the BMZs of the salivary glands (including in serous acini and excretory duct cell junctions), IgG was positive to some unique cells that may be stem cells. Unique individual cells resembling lymphocytes were positive with $\mathrm{C} 3 \mathrm{c}, \mathrm{C} 1 \mathrm{q}, \mathrm{IgE}$, and $\mathrm{IgG}$ in an opsonized manner. Several cell junctions were positive in the epidermis but did not show the classic fishnet-like intercellular stain between keratinocytes commonly seen in pemphigus. Rather the staining was dot-like and on cell junctions. 

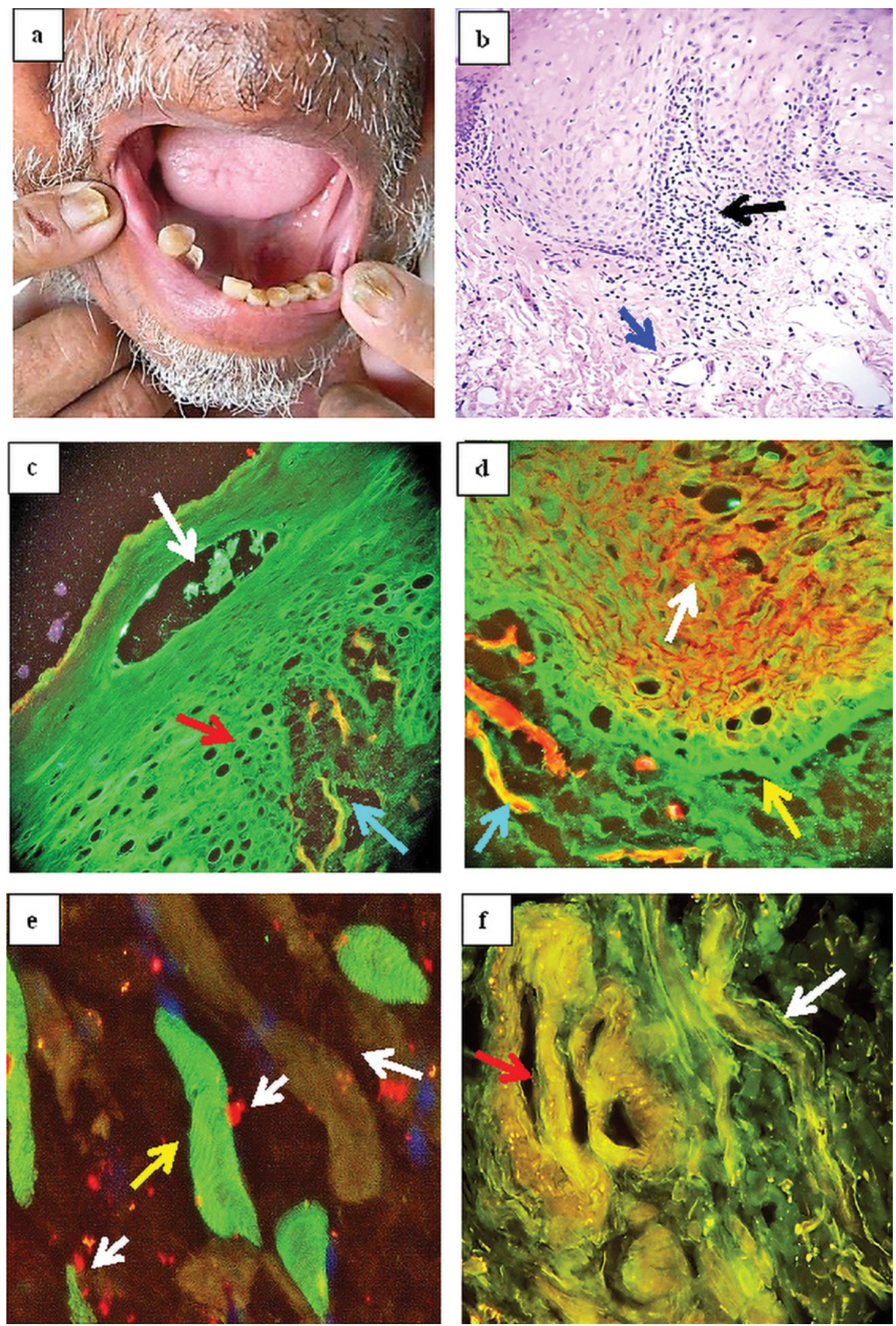

Figure 1. (a) Missing teeth in one El Bagre-EPF patient. (b) H\&E staining of the oral mucosa, showing edema in the mucosa; in the dermis, a lymphohistiocytic infiltrate (black arrow) and dilation of a blood vessel (blue arrow) (200x). (c) DIF showing positive staining with FITC conjugated anti-fibrinogen antibodies in intracorneal blister (light green staining; white arrow) and pericytoplasmic staining of the epidermal keratinocytes (light green staining; red arrow) (200x) and stain in the vessels (yellow-green staining; light blue arrow). (d) DIF showing positive staining with FITC conjugated IgG antibodies against the BMZ (green staining; yellow arrow), as well as against upper dermal blood vessels with ULEX (yellow staining, resulting from the colocalization of FITC [green] and Texas red [red]; light blue arrow) (200x). (e) DIF showing positive staining with FITC conjugated fibrinogen antibodies (green staining), colocalizing with MYZAP Alexa Fluor 555 against skeletal muscle (yellow arrow), as well as their cell junctions (red staining; white arrows) (200x). (f) DIF showing positive staining with FITC conjugated $\mathrm{C} 3 \mathrm{c}$ antibodies against the acini of the salivary glands (yellow staining; red arrow) and colocalizing with MYZAP in a salivary duct with Alexa Fluor 555 (white arrow; 400x). [Copyright: @2018 Abreu-Velez et al.] 
TABLE 1. DIF autoantibody staining in the oral mucosal structures, compared with the skin and colocalization with DP I-II, ARVCF, and p0071 autoantibodies

\begin{tabular}{|c|c|c|c|c|c|c|}
\hline \multicolumn{7}{|c|}{ DIF } \\
\hline Antibodies & $\begin{array}{c}\text { Oral } \\
\text { Positivity }\end{array}$ & $\begin{array}{c}\text { Strength } \\
\text { of } \\
\text { Staining }\end{array}$ & $\begin{array}{c}\text { Positivity to Oral Mucosa } \\
\text { Structures }\end{array}$ & $\begin{array}{l}\text { Colocalization } \\
\text { with ARVCF, } \\
\text { DP-I-II, p0071, } \\
\text { and MYZAP }\end{array}$ & $\begin{array}{l}\text { Positivity } \\
\text { in Skin }\end{array}$ & $\begin{array}{c}\text { Strength } \\
\text { of } \\
\text { Staining }\end{array}$ \\
\hline $\operatorname{IgG}$ & $40 / 45$ & $(+++)$ & $\begin{array}{l}\text { Epithelial cell junction dot staining. } \\
\text { Some stem cells like at the BMZ. The } \\
\text { neurovascular bundles and salivary } \\
\text { glands including their serous acini } \\
\text { and excretory ducts, mainly their cell } \\
\text { junctions. Neutrophil extracellular } \\
\text { traps. Cell junctions in the dermal } \\
\text { connective tissue. Unique individual } \\
\text { cells, resembling lymphocytes in } \\
\text { shape with "opsonized" features. }\end{array}$ & $100 \%$ & $40 / 45$ & $(+++)$ \\
\hline Fibrinogen & $39 / 45$ & $(+++)$ & $\begin{array}{l}\text { Intracorneal and subcorneal } \\
\text { blisters. Intracytoplasmic and } \\
\text { pericytoplasmic staining on } \\
\text { keratinocytes (uneven pattern). Dot } \\
\text { staining on cell junctions over the } \\
\text { entire mucosa. Cell junctions in the } \\
\text { dermal connective tissue. Skeletal } \\
\text { muscle staining. BMZ of the salivary } \\
\text { glands, its serous acini, and the } \\
\text { excretory ducts. Neurovascular } \\
\text { bundles. Encapsulated neural } \\
\text { receptors. }\end{array}$ & $100 \%$ & $39 / 45$ & $(+++)$ \\
\hline $\operatorname{IgM}$ & $38 / 45$ & $(+++)$ & $\begin{array}{l}\text { The mucosal corneal cell layer, } \\
\text { dot staining on cell junctions. The } \\
\text { BMZ, neurovascular bundles, } \\
\text { skeletal muscle, and some of } \\
\text { their intracellular organelles. The } \\
\text { BMZ of salivary glands, including } \\
\text { serous acini and excretory duct cell } \\
\text { junctions. Receptors linked with the } \\
\text { glands. }\end{array}$ & $100 \%$ & $38 / 45$ & $(+++)$ \\
\hline Albumin & $38 / 45$ & $(+++)$ & $\begin{array}{l}\text { Mucosal cell junction dot staining. } \\
\text { Salivary gland BMZs, their serous } \\
\text { acini and excretory duct cell } \\
\text { junctions. Cell junctions in the } \\
\text { dermal connective tissue. Large } \\
\text { neural receptors, colocalizing with } \\
\text { JAM-A. }\end{array}$ & $\begin{array}{l}100 \% \text { and with } \\
\text { JAM-A }\end{array}$ & $38 / 45$ & $(+++)$ \\
\hline $\begin{array}{l}\text { Complement/ } \\
\text { C3c }\end{array}$ & $35 / 45$ & $(+++)$ & $\begin{array}{l}\text { Cell junctions between keratinocytes. } \\
\text { Mucosal BMZ. Neural receptors } \\
\text { linked to the salivary glands. } \\
\text { BMZ of the salivary glands. } \\
\text { Neurovascular bundles. Skeletal } \\
\text { muscle cell junctions. Cell junctions } \\
\text { in the dermal connective tissue. } \\
\text { Unique individual cells resembling } \\
\text { lymphocytes in shape with } \\
\text { "opsonized" features. }\end{array}$ & $\begin{array}{l}100 \% \text { and with } \\
\text { JAM-A }\end{array}$ & $35 / 45$ & $(+++)$ \\
\hline
\end{tabular}


TABLE 1. DIF autoantibody staining in the oral mucosal structures, compared with the skin and colocalization with DP I-II, ARVCF, and p0071 autoantibodies (continued)

\begin{tabular}{|c|c|c|c|c|c|c|}
\hline \multicolumn{7}{|c|}{ DIF } \\
\hline Antibodies & $\begin{array}{l}\text { Oral } \\
\text { Positivity }\end{array}$ & $\begin{array}{c}\text { Strength } \\
\text { of } \\
\text { Staining }\end{array}$ & $\begin{array}{l}\text { Positivity to Oral Mucosa } \\
\text { Structures }\end{array}$ & $\begin{array}{l}\text { Colocalization } \\
\text { with ARVCF, } \\
\text { DP-I-II, p0071, } \\
\text { and MYZAP }\end{array}$ & $\begin{array}{l}\text { Positivity } \\
\text { in Skin }\end{array}$ & $\begin{array}{c}\text { Strength } \\
\text { of } \\
\text { Staining }\end{array}$ \\
\hline $\begin{array}{l}\text { Complement/ } \\
\text { C1q }\end{array}$ & $35 / 45$ & $(++)$ & $\begin{array}{l}\text { Cytoplasm of mucosal keratinocytes, } \\
\text { patchy; dot staining in the BMZ cell } \\
\text { junctions and in the salivary glands } \\
\text { and their ducts. Striated muscle and } \\
\text { its cell junctions. Neural receptors } \\
\text { in the salivary glands. Cell junctions } \\
\text { in the dermal connective tissue. } \\
\text { Unique individual cells resembling } \\
\text { lymphocytes in shape lymphocytes, } \\
\text { with "opsonized" features that } \\
\text { colocalize with CD3. }\end{array}$ & $\begin{array}{l}100 \% \text { and } \\
\text { JAM-A }\end{array}$ & $35 / 45$ & $(++)$ \\
\hline $\begin{array}{l}\text { Complement/ } \\
\text { C4 }\end{array}$ & $17 / 45$ & & $\begin{array}{l}\text { Epithelium, BMZ, and striated } \\
\text { muscle. }\end{array}$ & & $17 / 45$ & \\
\hline $\operatorname{IgA}$ & $17 / 45$ & $(++)$ & $\begin{array}{l}\text { Corneal layer, epithelial dot } \\
\text { staining on cell junctions, and } \\
\text { pericytoplasmic cell staining in the } \\
\text { basaloid layer. Salivary ducts as } \\
\text { well as smooth muscle and skeletal } \\
\text { muscle, and basal layer cells. } \\
\text { Connective tissue cell junctions. } \\
\text { Neural receptors in the glands. }\end{array}$ & $100 \%$ & $39 / 45$ & $(++)$ \\
\hline IgD & $16 / 45$ & $(++)$ & $\begin{array}{l}\text { Skeletal muscle and its cell junctions. } \\
\text { Positive on neurovascular supply } \\
\text { structures under the BMZ. Positive } \\
\text { on ducts of the salivary glands. }\end{array}$ & $100 \%$ & $16 / 45$ & $(++)$ \\
\hline $\operatorname{IgE}$ & $7 / 45$ & $(++)$ & $\begin{array}{l}\text { Receptors in the salivary glands. } \\
\text { Unique individual cells resembling } \\
\text { lymphocytes in shape, with } \\
\text { "opsonized" features that colocalize } \\
\text { with CD3. }\end{array}$ & $100 \%$ & $7 / 45$ & $(++)$ \\
\hline Lambda & $40 / 45$ & $(+++)$ & $\begin{array}{l}\text { Staining on subcorneal blisters and } \\
\text { epithelial cell junctions. On salivary } \\
\text { glands, including their serous } \\
\text { acini and excretory ducts. Skeletal } \\
\text { muscle and its cell junctions and on } \\
\text { connective tissue cell junctions. }\end{array}$ & $100 \%$ & $40 / 45$ & $(+++)$ \\
\hline Kappa & $40 / 45$ & $(+++)$ & $\begin{array}{l}\text { Staining on subcorneal blisters } \\
\text { and epithelial cell junctions. On } \\
\text { salivary glands including their serous } \\
\text { acini and excretory ducts. Skeletal } \\
\text { muscle and its cell junctions and on } \\
\text { connective tissue cell junctions. }\end{array}$ & $100 \%$ & $40 / 45$ & $(+++)$ \\
\hline
\end{tabular}

\section{IHC Staining}

Using metallothionein we observed patchy spot staining at the BMZ, as well as in the neurovascular bundles, the salivary glands including serous acini and the excretory ducts, cell junctions, striated muscle, mesenchymal-endothelial cell junction connective tissue (mainly against the cell junctions), and inside some striated muscle organelles. TIMP1 was positive in the corneal layer and the upper epidermal layers in some patients, and in others in the lower epithelial layers and in the cell junctions of the vessels and cell junctions of the salivary ducts (Figure 3). 

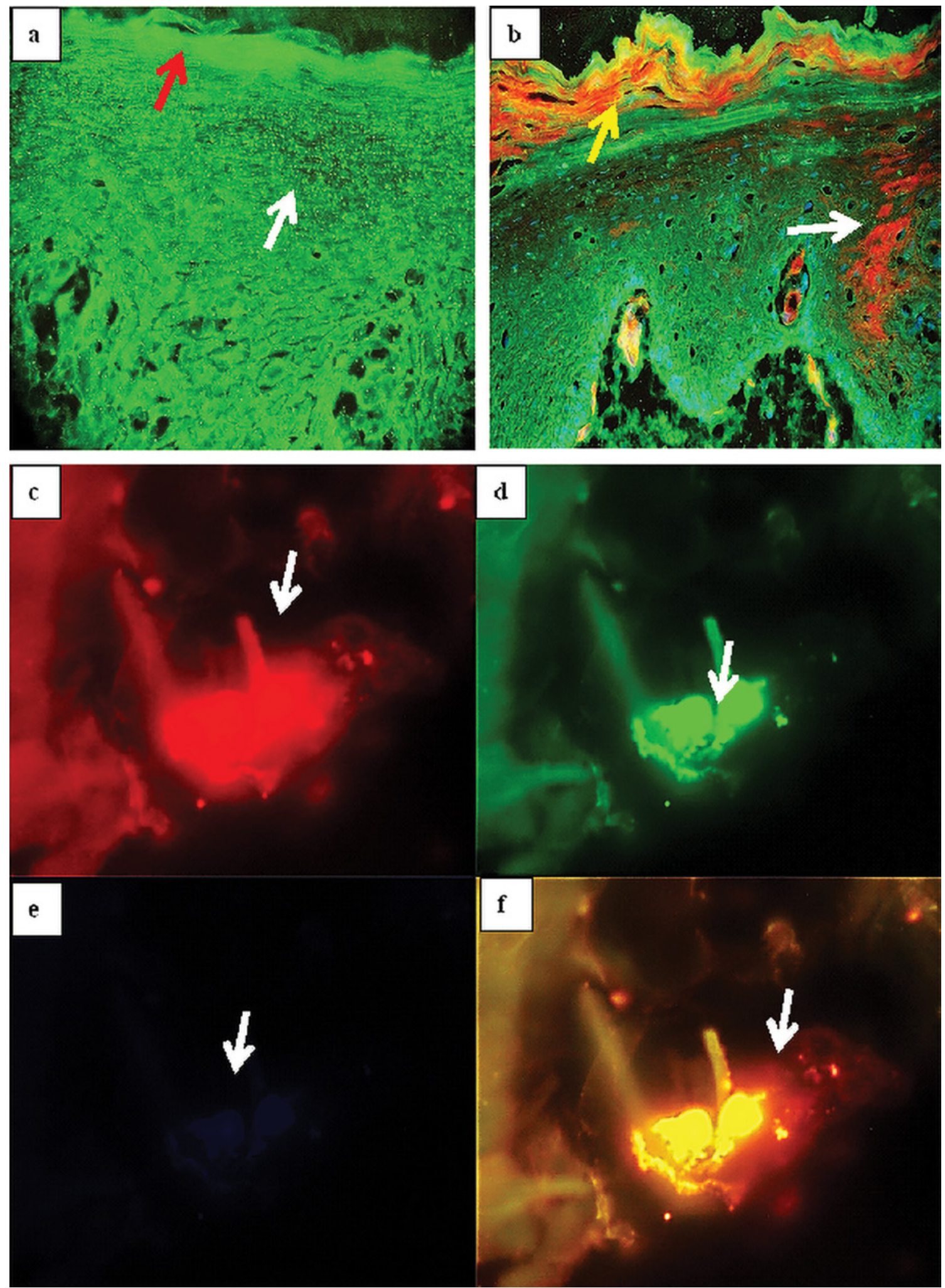

Figure 2. (a) DIF showing positive dot staining with FITC conjugated IgG antibodies against epithelial cell junctions (light green staining; white arrow) (200x) and in the corneal layer (light green staining; red arrow). (b) DIF showing positive staining with FITC conjugated IgG antibodies against the corneal layer (yellow staining; yellow arrow) and dot cell junction staining in epithelial cells (light green staining; white arrow). ARVCF staining with Alexa Fluor 555 is noted in a salivary gland duct (red staining; white arrow) (200x) and in the corneal layer (red staining; yellow arrow). (c-f) Confocal microscopy, using multiple channels of fluorescence. In c, we used antibody to IgM FITC channel (excitation/emission, 495/519 nm); in (d) an antibody to p0071 (Texas red, 555 channel) (excitation/emission, $555 / 568 \mathrm{~nm}$ ); in (e) a DAPI channel (blue) (excitation/emission, 360/460 nm); and in $\mathrm{f}$, the combination of all showing a perfect colocalization against neuroreceptors in a salivary gland (in c-f, white arrows, 1,000×). [Copyright: @2018 Abreu-Velez et al.] 

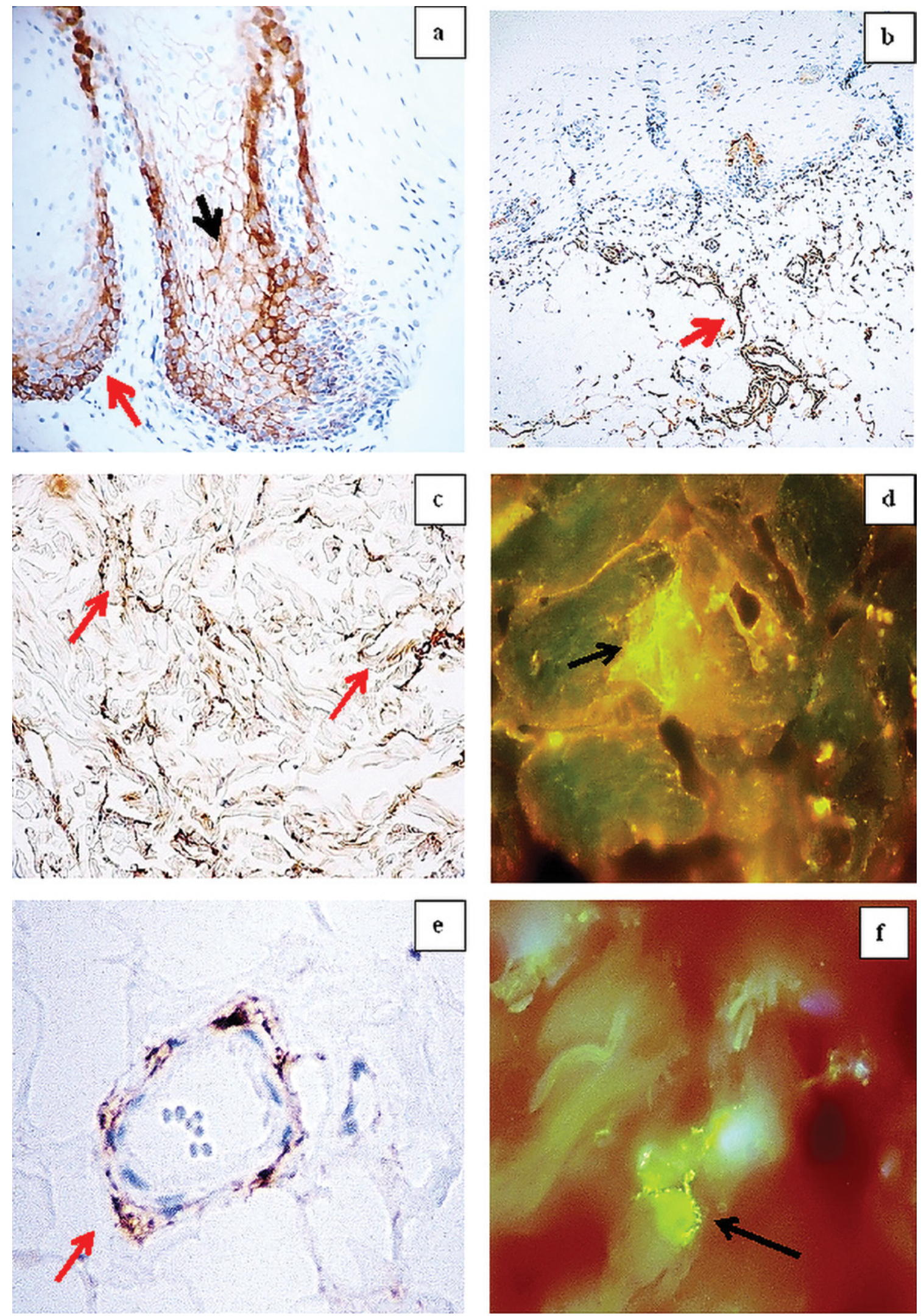

Figure 3. (a) IHC positive staining for metallothionein between oral mucosal cell junctions (black arrow) as well as at the BMZ (brown staining; red arrow; 200x). (b) IHC positive staining for IgA on neurovascular dermal structures (brown staining; red arrow) (100x). (c) IHC positive staining mesenchymal-endothelial junctions in dermal connective tissue cell junctions (brown staining; red arrow)(200x). (d) DIF, showing positive staining with IgA FITC conjugate on dermal connective tissue cell junctions (black arrow) colocalizing with ARVCF conjugate with Alexa Fluor 555 (400x). (e) IHC positive staining with metallothionein in a salivary gland (brown staining; red arrow)(400x). (f) DIF positive staining with FITC conjugated C1q, colocalizing with Texas red DP I-II in the oral mucosa (black arrow, 1,000x). [Copyright: (O2018 Abreu-Velez et al.] 


\section{Conclusions}

Herein, we report for the first time that patients affected by a new variant of EPF in El Bagre, Colombia, have oral manifestations. The main clinical finding was the asymptomatic loss of teeth, and the main pathological finding was subcorneal blistering. The asymptomatic autoimmune response is directed at multiple structures in the oral mucosa, primarily to cell junctions of the epithelia, dermis, salivary glands, and vessels. We also describe for the first time that the intrinsic oral mucosal immune system, including IgA and secretory IgA, appears to play an important role in this asymptomatic autoimmunity. Previously, we showed that El Bagre-EPF patients have a polyclonal immune response in the skin and against other organs involving $\operatorname{Ig} \mathrm{A}$ [12-15].

In this case-control study we found some clinical alterations such as loss of teeth in the El Bagre-EPF group. Prednisone therapy and lack of oral hygiene can explain these findings. However, the controls have similar demographic factors, with the exception of the intake of prednisone. The autoantibodies to the periodontal ligament could contribute to weakness of the patients' teeth. We previously reported autoantibodies to several smooth muscle structures including the arrector pili muscle in most El Bagre-EPF patients [13].

In theory, clinical involvement of the oral mucosa is not typically present in pemphigus foliaceus. Previously published data indicate that in pemphigus foliaceus, desmoglein 1 (Dsg1) and desmoglein 3 (Dsg3) are expressed in a pathogenic distribution throughout the squamous mucosal epithelia and the skin [16-18]. In our data, we observed something completely different that contradicts this hypothesis, ie, the "theory of Dsg1-Dsg3 compensation."

Measuring salivation in the endemic area is also difficult, but with use of multicolor immunofluorescence [19] we were able to observe positivity to neuroreceptors using high magnifications and color contrast. We also previously demonstrated that the El Bagre-EPF patients have autoantibodies to their palms and soles, as well as to their sweat glands with an IgA response (immune-specific to these anatomic sites) [20,21].

Our findings pointed us to an $\operatorname{Ig} \mathrm{A}$ autoimmune response that is part of the mucosal innate immunity, including the saliva containing lysozymes, bacteriocidins, defensins, cationic proteins, and lactoferrin [22]. Our findings brought our attention to the specific immunity that the oral mucosa has in comparison with the skin. Tomasi and his colleagues in the mid-1960s originally documented oral "local immunity" with the presence of IgA antibodies in secretions including saliva [23-25].

A group of Brazilian authors performed a study of the oral cavity of 56 patients with fogo selvagem (FS). Histopathological and clinical examination of the gingivae of 8 patients revealed FS in the acute and bullous phases of the disease and significant periodontal disease [26].

Other authors studied 15 patients with FS reporting subcorneal acantholysis and no oral blisters or erosions, but DIF demonstrated the presence of tissue-bound autoantibodies in both the epidermis and the oral epithelium of all patients [6].

Other authors studied patients with FS and 4 control subjects, examining the oral mucosa using electron microscopy. In addition to showing clinically normal oral mucosa, electron microscopy showed widening of the intercellular spaces between keratinocytes [6-11].

We observed an autoimmune response to neural receptors in El Bagre-EPF patients' oral mucosa and salivary glands; indeed, we have described autoreactivity to skin neurovascular structures and neural receptors in previous studies $[27,28]$. The neuronal/transmitter control of salivary glands is performed by both dopaminergic and serotonergic neurons and receptors [29]. Both classes of transmitters elicit saliva secretion. The neurons contain $\gamma$-aminobutyric acid (GABA). GABA-positive fibers form a network around most salivary acinar lobules and a dense plexus in the interior of a minor fraction of acinar lobules.

We conclude that patients affected by El Bagre-EPF have an autoimmune response in the oral mucosa. We suggest that this process results in loss of teeth; $\operatorname{IgA}$, and the mucosal immune system seem to play important roles. Given our observations, the Dsg1-Dsg3 compensation theory offered to explain a "lack" of oral compromise in pemphigus foliaceus (including its endemic variants) may need reassessment.

\section{References}

1. Abreu Velez AM, Hashimoto T, Bollag W, et al. A unique form of endemic pemphigus in Northern Colombia. J Am Acad Dermatol. 2003;49(4):599-608.

2. Abreu Velez AM, Beutner EH, Montoya F, Hashimoto T. Analyses of autoantigens in a new form of endemic pemphigus foliaceus in Colombia. J Am Acad Dermatol. 2003;49(4):609-614.

3. Hisamatsu Y, Abreu Velez AM, Amagai M et al. Comparative study of autoantigen profile between Colombian and Brazilian types of endemic pemphigus foliaceus by various biochemical and molecular biological techniques. J Dermatol Sci. 2003;32(1):33-41.

4. Abreu Velez AM, Javier Patiño P, Montoya F, et al. The tryptic cleavage product of the mature form of the bovine desmoglein 1 ectodomain is one of the antigen moieties immunoprecipitated by all sera from symptomatic patients affected by a new variant of endemic pemphigus. Eur J Dermatol. 2003;13(4):359-366.

5. Abréu Vélez AM, Yepes MM, Patiño PJ, Bollag WB, Montoya F Sr. A cost-effective, sensitive and specific enzyme linked immunosorbent assay useful for detecting a heterogeneous antibody population in sera from people suffering a new variant of endemic pemphigus. Arch Dermatol Res. 2004;295(10):434-441.

6. Lacaz Netto R, Macedo NL. Pemphigus foliaceus: a clinical histopathological study of the gingiva [in Portuguese]. Rev Odontol UNESP. 1983;12: 61-69. 
7. Sotto MN, Shimizu SH, Costa JM, et al. South American pemphigus foliaceus: electron microscopy and immunoelectron localization of bound immunoglobulin in the skin and oral mucosa. $\mathrm{Br}$ J Dermatol. 1980;102(5):521-527.

8. Marcucci G, Cucé LC, Sotto MN, et al. Contribuição ao estudo da ultra-estrutura da mucosa bucal em doentes de pênfigo foliáceo brasileiro. Rev Fac Odontol Univ São Paulo. 1982;205-225.

9. Hietanen J, Salo OP, Kanerva L, et al. Ultrastructure of uninvolved oral mucosa in pemphigus patients. Acta Derm Venereol.1983;63(6):63491-63494.

10. Rivitti EA, Sanches JA, Miyauchi LM, et al. Pemphigus foliaceus autoantibodies bind both epidermis and squamous mucosal epithelium, but tissue injury is detected only in the epidermis. $J$ Am Acad Dermatol. 1994;31(6):31954-31958.

11. Guedes AC, Rotta O, Leite HV, et al. Ultrastructural aspects of mucosas in endemic pemphigus foliaceus. Arch Dermatol. 2002;138(7):949-954.

12. Abreu-Velez AM, Howard MS, Yi H,et al. Patients affected by a new variant of endemic pemphigus foliaceus have autoantibodies colocalizing with MYZAP, p0071, desmoplakins 1-2 and ARVCF, causing renal damage. Clin Exp Dermatol. 2018;43(6):692-702.

13. Abreu-Velez AM, Valencia-Yepes CA, Upegui-Zapata YA, et al. Patients with a new variant of endemic pemphigus foliaceus have autoantibodies against arrector pili muscle, colocalizing with MYZAP, p0071, desmoplakins 1 and 2 and ARVCF. Clin Exp Dermatol. 2017;42(8):874-880.

14. Abreu-Velez AM, Gao W, Howard MS.Patients affected by endemic pemphigus foliaceus in Colombia, South America exhibit autoantibodies to optic nerve sheath envelope cell junctions. Dermatol Pract Concept. 2018; 31;8(1):1-6.

15. Abreu Velez AM, Howard MS, Velazquez-Velez JE. Cardiac rhythm and pacemaking abnormalities in patients affected by endemic pemphigus in Colombia may be the result of deposition of autoantibodies, complement, fibrinogen, and other molecules. Heart Rhythm. 2018;15(5):725-731.

16. Shirakata Y, Amagai M, Hanakawa Y, et al. Lack of mucosal involvement in pemphigus foliaceus may be due to low expression of desmoglein 1. J Invest Dermatol. 1998;110(1):76-78.

17. Mahoney MG, Wang Z, Rothenberger K, Koch PJ, Amagai M, Stanley JR. Explanations for the clinical and microscopic localization of lesions in pemphigus foliaceus and vulgaris. J Clin Invest. 1999;103(4):461-468.
18. Amagai M, Tsunoda K, Zillikens D, et al. The clinical phenotype of pemphigus is defined by the anti-desmoglein autoantibody profile. J Am Acad Dermatol. 1999;40(2 Pt 1):167-170.

19. Abreu Velez AM, Upegui Zapata YA, Howard MS. Periodic acid-Schiff staining parallels the immunoreactivity seen by direct immunofluorescence in autoimmune skin diseases. N Am J Med Sci. 2016;8(3):151-155.

20. Abreu Velez AM, Howard MS, Hashimoto T. Palms with a polyclonal autoimmune response in patients affected by a new variant of endemic pemphigus foliaceus in Colombia, South America. Eur J Dermatol. 2010;20(1):74-81.

21. Abreu Velez AM, Howard MS, Hashimoto K, et al. Autoantibodies to sweat glands detected by different methods in serum and in tissue from patients affected by a new variant of endemic pemphigus foliaceus. Arch Dermatol Res. 2009;301(10):711-718.

22. Feller L, Altini M, Khammissa RA, et al. Oral mucosal immunity. Oral Surg Oral Med Oral Pathol Oral Radiol. 2013;116(5):576583.

23. Tomasi TB Jr, Zigelbaum S. The selective occurrence of gamma-1a globulins in certain body fluids. J Clin Invest. 1963 Oct;42:15521560 .

24. Chodirker WB Tomasi TB Jr. Gamma-globulins: quantitative relationships in human serum and nonvascular fluids. Science. 1963;142(3595):1080-1081.

25. Tomasi TB Jr, Tan EM, Solomon A, Prendergast RA. Characteristics of an immune system common to certain external secretions. J Exp Med. 1965 Jan 1;121:101-124.

26. Russel AL. A system of classification and scoring for prevalence surveys of periodontal disease. J Dent Res. 1956;35(3):350-359.

27. Abreu-Velez AM, Howard MS, Yi H, Gao W, et al. Neural system antigens are recognized by autoantibodies from patients affected by a new variant of endemic pemphigus foliaceus in Colombia. $J$ Clin Immunol. 2011;31(3):356-368.

28. Abreu Velez AM, Yi H, Warfvinge G, Howard MS. Autoantibodies to full body vascular cell junctions colocalize with MYZAP, ARVCF, desmoplakins I and II and p0071 in endemic pemphigus in Colombia, South America. Int J Dermatol. 2018;57(3):291298.

29. Habre-Hallage P, Dricot L, Hermoye L, et al. Cortical activation resulting from the stimulation of periodontal mechanoreceptors measured by functional magnetic resonance imaging (fMRI). Clin Oral Investig. 2014;18(8):1949-1961. 